\title{
Assessment Land Cover Change Using Normalized Difference Water Index (NDWI) In Bakun Reservoir, Sarawak.
}

\author{
Ricky Anak Kemarau and Oliver Valentine Eboy \\ Geography Program, Faculty of Social Science and Humanities, \\ University Malaysia Sabah, \\ Jalan UMS, 88400 Kota Kinabalu, Sabah, Malaysia.
}

\begin{abstract}
The location of Sarawak State in the equatorial region makes it an area of high rainfall. For this reason, hydroelectric power plants have been built in several catchments in Sarawak, especially in the Kapit area. This needs to be harnessed to improve the economy and social living standards of the people of Sarawak in particular. This paper presents the land cover change by analyzing the stratification change for 30 years (1985-2018) at Bakun Dam, Sarawak. This study uses Landsat 5 and Landsat 8 satellite data. Both data have to go through pre-processing such as geometric, radiometric, and atmospheric corrections. In this study, Normalized Water Difference Index (NDWI) is used to classify water areas, built human areas, and vegetation areas. Overlay analysis was applied to identify areas that had changed over the 30 years in the study area. The results showed the greatest changes from vegetation areas to water bodies for 30 years. The results showed that the most affected land cover was forest cover with a reduction of $740 \mathrm{~km}^{2}$, which shifted mainly to water bodies with $669.9 \mathrm{~km}^{2}$ and human development with an area of $68.7 \mathrm{~km}^{2}$. The study area is less populated and anthropogenic influences are rather low, but deforestation is observed in the upper river basin. These events would change the hydrological behavior of these catchments in the future. Land cover mapping is very important to provide information to those responsible for planning sustainable development. In addition, land cover maps are important for land use planning and land use regulation to avoid land-use conflicts.
\end{abstract}

Keywords: Land Cover Drivers, Change Detection, NDWI, Hydropower Plant.

\section{INTRODUCTION}

Krishna et al. [1] showed that in Southeast Asian countries (such as Indonesia, Malaysia, Singapore, Thailand, Vietnam, and Cambodia), rapid land cover change is occurring. This rapid change is due to population growth, urban expansion, and large structures such as dams. Due to the energy demand and abundance of rainfall, hydropower plants are the best alternative to provide electricity to the people in the state of Sarawak to improve the economy and society. Monitoring, recording, and documenting land cover change is very important in Malaysia as the product can be useful for advising policymakers and improved land management [2]. Generally, traditional methods are still used for land cover mapping in developing countries. This method is time-consuming and expensive compared to remote sensing technology. The technology is capable of providing data in multitemporal, synoptic, and repeated forms. Thus, remote sensing provides a practical and best tool for mapping and calculating land cover changes at different scales, times, and locations [3; 4;5]. A review of the literature has focused on land cover change detection using different models, methods, and satellite imagery, namely [6] using normalized vegetation difference index (NDVI), principal component analysis (PCA). Nutini et al, [7] performed multitemporal analysis and Landsat

Corresponding Author: Ricky Anak Kemarau, Faculty of Social Science and Humanities, University Malaysia Sabah, Jalan UMS, 88400 Kota Kinabalu, Sabah, Malaysia, ricky.geo2005@gmail.com

imagery; Kim et al [8] used Landsat imagery; Mayes et al [9] assumed Landsat 5-8 data and linear spectral mixture analysis; Choudhary and Pathak [10] investigated land-use change detection using Landsat TM imagery. ETM and OLI; Leite et al [11] used Landsat 5 / TM imagery and geographic objects; Sidhu et al [12] used Google Earth to map land cover change; Zoungrana et al [18] used MODIS satellite imagery to detect land cover change. There is a need to investigate future changes in catchment characteristics/land-use changes and their impact on river water yield. Land cover information is critical because the study area will be used as a reservoir in the future on a stationary basis. The latest update of land cover is important for the authorities to declare the areas as forest reserves and protect them properly to mitigate sedimentation problems in the rivers. Moreover, there is no previous work in the literature analyzing land cover change in Bakun, Sarawak. To overcome this challenge, the researchers used remote sensing data with a spatial resolution of 30 meters for 30 years (1990-2020) to identify the land change between the year when the construction of the hydropower plant began and the current period. 


\section{METHODOLOGY}

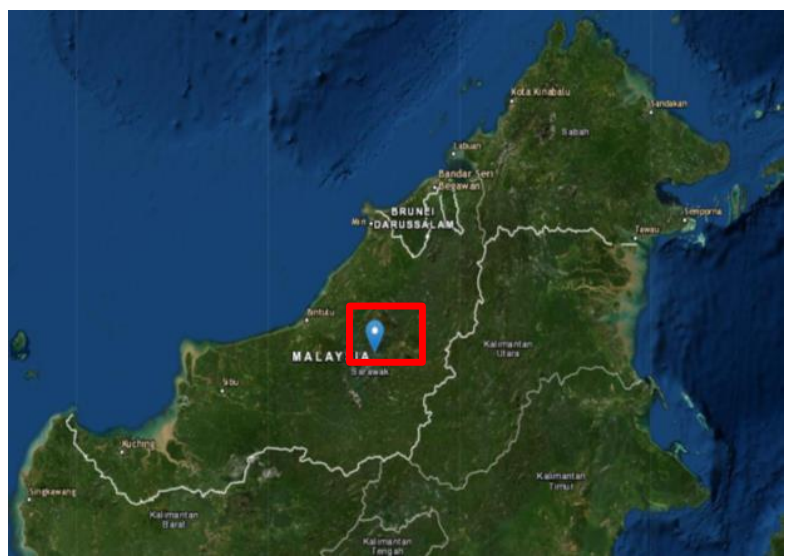

Fig 1 Location of Study

The Bakun Hydroelectric Dam is located at Batang Balui, the headwaters of the Rajang River, Kapit Division. The Bakun Hydroelectric Dam is located about $37 \mathrm{~km}$ upstream from the town of Belaga [13]. Bakun Hydroelectric Power power plant capacity of 2,400 MW [13].

Table 1: Information of dataset.

\begin{tabular}{|c|c|}
\hline Sensor & Data Acquisition \\
\hline $\begin{array}{c}\text { Landsat 5 Thermatic } \\
\text { Mapper (TM) }\end{array}$ & 25 May 1990 \\
\hline $\begin{array}{c}\text { Landsat 8 Operational } \\
\text { land Imager (OLI) and } \\
\text { Thermal Infrared Sensor } \\
\text { (TIRS) }\end{array}$ & 21 August 2020 \\
\hline
\end{tabular}

Data from Landsat 5 TM and 8 OLI TIRS satellites were used for this study, as shown in Table 1. Cloud cover less than $10 \%$.

Table 2: Information of Landsat 5 TM.

\begin{tabular}{|c|c|}
\hline Landsat 5 TM & Wavelength (micrometer) \\
\hline Band 1 & $0.43-0.45$ \\
\hline Band 2 & $0.45-0.61$ \\
\hline Band 3 & $0.53-0.59$ \\
\hline Band 4 & $0.64-0.67$ \\
\hline Band 5 & $0.85-0.88$ \\
\hline Band 6 & $1.57-1.65$ \\
\hline Band 7 & $2.11-2.29$ \\
\hline Band 8 & -0.68 \\
\hline
\end{tabular}

Table 2 shows the bands available in Landsat 5TM. Previous studies have proposed the use of bands 3 and 5 for Landsat 5 and obtained good results in terms of accuracy assessment $[14 ; 6 ; 18]$. The main challenge of this study is the location in the highlands. Factors such as mountain and hill shadows greatly affect the results when mapping the study area. $[13 ; 14 ; 6 ; 18]$ produce the Normalized Water
Difference Index (NDWI). The NDWI at Landsat 5 TM can be generated using the following formula:

$$
\text { NDWI }=(\text { Band } 3-\text { Band } 5) /(\text { Band } 3+\text { Band } 5) .
$$

\begin{tabular}{|l|l|}
\hline Landsat 8 OLI and TIRS & $\begin{array}{l}\text { Wavelength } \\
\text { (Micrometers) }\end{array}$ \\
\hline Band 1 - Coastal Aerosol & $0.45-0.52$ \\
\hline Band 2 & $0.52-0.60$ \\
\hline Band 3 & $0.63-0.69$ \\
\hline Band 4 & $0.76-0.90$ \\
\hline Band 5 & $1.55-1.75$ \\
\hline Band 6 & $10.40-12.50$ \\
\hline Band 7 & $2.08-2.35$ \\
\hline Band 8-panchromatic & $0.50-0.68$ \\
\hline Band 9-cirrus & $1.36-1.38$ \\
\hline $\begin{array}{l}\text { Band 10 Thermal Infrared } \\
1\end{array}$ & $10.6-11.19$ \\
\hline $\begin{array}{l}\text { Band 11 Thermal Infrared } \\
2\end{array}$ & $11.50-12.51$ \\
\hline
\end{tabular}

Landsat 8 requires band five and band six to generate NDWI as mentioned formula below $[13 ; 14 ; 3 ; 18]$.

$$
\text { NDWI }=(\text { Band } 5-\text { Band } 6) /(\text { Band } 5+\text { Band } 6)
$$

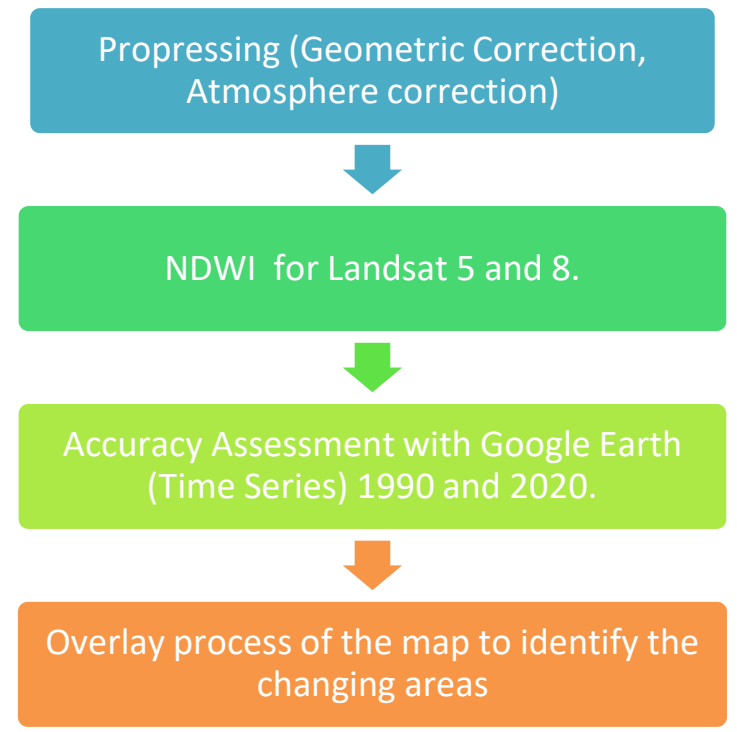

Fig 2 Flow Methodology

Figure 2 shows the steps taken to achieve the objectives of the study. The first step is to perform pre-processing such as atmospheric, radiometric, and geometric corrections. The second step is to generate the NDWI based on the widely used formula. The next step is required for the calculated area of each land cover on the attribute data in ArcGIS. The 1990 and 2020 land cover maps are subjected to change detection and overlay in the ArcGIS tool to identify the changing areas. The final step is to evaluate the accuracy of the 1990 and 2020 land cover maps using a time series analysis in Google Earth as practiced by Ricky and Oliver [2]. 


\section{Result and Discussion}

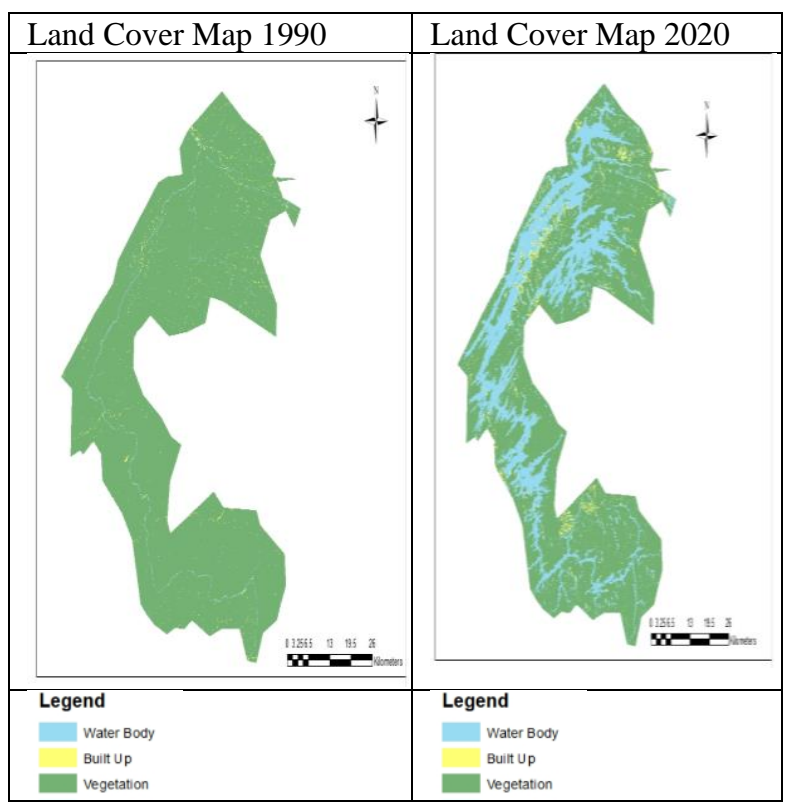

Figure 3: Land cover map between 1990 and 2020.

See Figure 3 for the observed major change in vegetation between the years 1990 and 2020. In 1990, the figure shows that vegetation area was the largest area in the study area compared to water bodies and development. The year 2020 also shows that vegetation areas are still the largest areas compared to developed areas and water bodies. Detailed explanations of land cover change can be found in Figure 4.

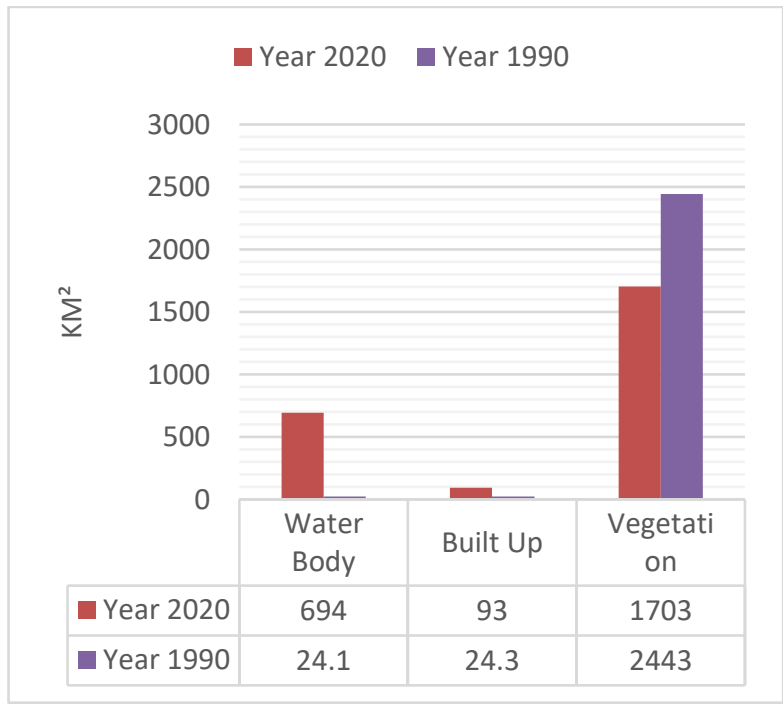

Figure 4 Land Cover Change in $\mathrm{km}^{2}$.

In 1990, the vegetation areas were $2443 \mathrm{~km}^{2}$, the secondlargest areas were built-up/built-over areas with a total area of $24.1 \mathrm{~km}^{2}$, and the built-up areas or water bodies were the third largest with $24.3 \mathrm{~km}^{2}$. The year 2020 shows the largest areas still vegetation with a total area of $1703 \mathrm{~km}^{2}$, second- largest is a water area is $694 \mathrm{~km}^{2}$ and last built/developed areas with total areas $93 \mathrm{~km}^{2}$. The result of this study showed the total area water area of $694 \mathrm{~km}^{2}$, which is almost similar to the total areas from the report on Sarawak Energy [16] and Bakun HEP Design Report [17] with a total water body area of $695 \mathrm{~km}^{2}$ [13]. The detailed land cover change information is explained in Figure 5.

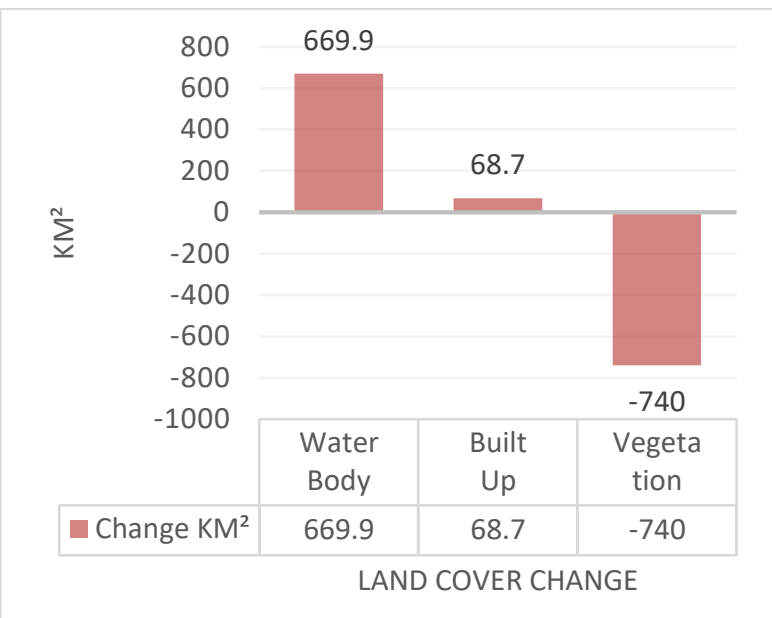

Figure 5: The change in the land cover area in the Bakun area in 1990 and 2020.

This study shows the largest change in vegetation area to water bodies and built-up areas, which decreased by 740.5 $\mathrm{km}^{2}$. The second-largest change in vegetation area and built-up areas to the water body increased to $669.9 \mathrm{~km}^{2}$. In addition, the change from vegetation area to the built-up area increased by $68.7 \mathrm{~km}^{2}$.

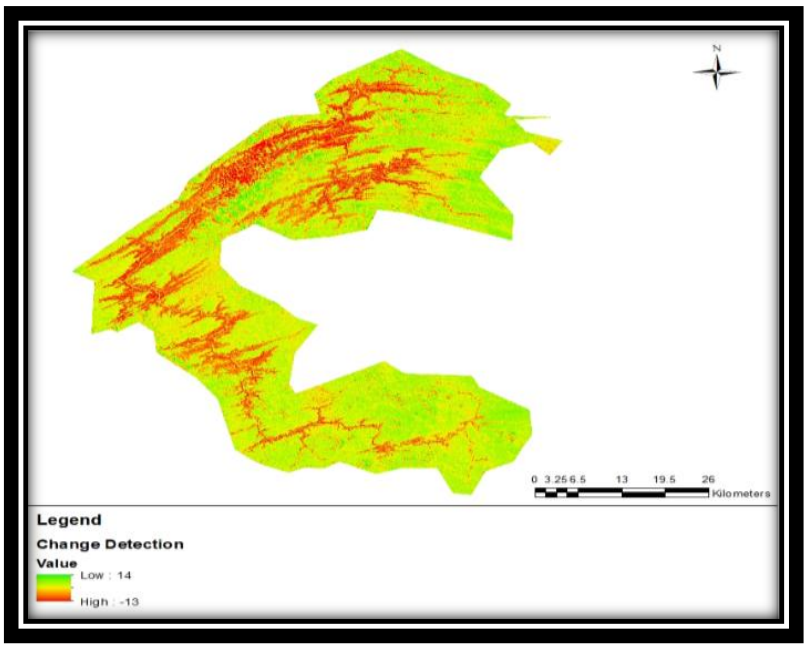

Figure 6 Land cover change detection between the years 1990 and 2020.

The red-colored area distinguishes the variable change between the years 1990 and 2020. Figure 6 clearly shows the vegetation areas replace by a water body, which indicates -13 , the importance brings a decrease in the areas of vegetation to the water body. 


\section{CONCLUSION}

The results of this study found that there was a change in the area of plant area to the water body. This study also found that a land cover map using the NDWI index can give good results, similar to the result in Ozelkan [14]. This study found that there is a difference of only $2 \mathrm{~km}^{2}$ compared to the report of Sarawak Energy. NDWI can produce land cover maps for 1990 and 2020 using Landsat 5TM and 8 satellites OLI TIR. To determine the accuracy of land cover 1990 dan 2020. mapped land cover 1990 to 2020 was compared with Google Earth through time series analysis. The resulting land cover information was confirmed and corrected. Monitoring, tracking, and documenting land cover is important for policymakers and regional planners to understand the impact of land cover on the environment and society. In addition, a land cover map is important as a base map for land management and regional planning in the future.

\section{ACKNOWLEDGMENTS}

Thanks to NASA for providing the free access data policy.

\section{REFERENCES}

[1] Krishna Vadrevu, Andreas Heinimann, Garik Gutman \& Chris Justice (2019) Remote sensing of land use/cover changes in South and Southeast Asian Countries, International Journal of Digital Earth, 12:10, 10991102, DOI: 10.1080/17538947.2019.1654274

[2] Ricky Anak Kemarau and Oliver Valentine Eboy (2021). Land Cover Change Detection in Kuching, Malaysia Using Satellite Imagery. Borneo Journal of Sciences \& Technology, Volume (3), Issue (1), Pages: 61-65 DOI: http://doi.org/10.3570/bjost.2021.3.1-09.

[3] Laborde, H., Douzal, V., Ruiz Piña, H. A., Morand, S., \& Cornu, J. F. (2017). Landsat-8 cloud-free observations in wet tropical areas: A case study in South East Asia. Remote Sensing Letters, 8(6), 537-546.

[4] Shimabukuro, Y. E., Beuchle, R., Grecchi, R. C., \& Achard, F. (2014). Assessment of forest degradation in Brazilian Amazon due to selective logging and fires using time series of fraction images derived from Landsat ETM+ images. Remote sensing letters, 5(9), 773-782.

[5] Cowie, A. L., Orr, B. J., Sanchez, V. M. C., Chasek, P., Crossman, N. D., Erlewein, A., ... \& Welton, S. (2018). Land in balance: The scientific conceptual framework for Land Degradation Neutrality. Environmental Science \& Policy, 79, 25-35.

[6] Ricky Anak Kemarau and Oliver Valentine Eboy (2019). Landscape Indices and Its Impacts on Land Surface Temperature on Small Medium Size City for the Year 1991, 2011 and 2018: Case Study Kota Kinabalu. Journal of Built Environment, Technology, and Engineering, Vol. 7 (Sept.) ISSN 0128-1003.

[7] Nutini, F., Boschetti, M., Brivio, P. A., Bocchi, S., \& Antoninetti, M. (2013). Land-use and land-cover change detection in a semi-arid area of Niger using multi- temporal analysis of Landsat images. International journal of remote sensing, 34(13), 4769-4790.

[8] Kim, D. H., Sexton, J. O., Noojipady, P., Huang, C., Anand, A., Channan, S.\& Townshend, J. R. (2014). Global, Landsat-based forest-cover change from 1990 to 2000. Remote sensing of environment, 155, 178-193.

[9] Mayes, M. T., Mustard, J. F., \& Melillo, J. M. (2015). Forest cover change in Miombo Woodlands: modeling land cover of African dry tropical forests with linear spectral mixture analysis. Remote sensing of environment, 165, 203-215.

[10] Choudhary, R., \& Pathak, D. (2016). Land use/land cover change detection through temporal imageries and its implications in water-induced disaster in Triyuga watershed, east Nepal. Journal of Nepal Geological Society, 51, 49-54.

[11] Leite, L. R., Carvalho, L. M. T. D., \& Silva, F. M. D. (2017). Change detection in forests and savannas using statistical analysis based on geographical objects. Boletim de Ciências Geodésicas, 23(2), 284295.

[12] Sidhu N, Pebesma E, and Câmara G. (2018) Using Google Earth Engine to detect land cover change: Singapore as a use case. European Journal of Remote Sensing. 2018;51(1):486-500.

[13] Tipol, F. H. B. (2019, November). Challenges in Preparation and Implementation of Dam Safety Emergency Plan for Hydroelectric Plants in Sarawak. In International Conference on Dam Safety Management and Engineering (pp. 1-9). Springer, Singapore.

[14] Özelkan, E. (2020). Waterbody detection analysis using NDWI indices derived from Landsat-8 OLI. Polish Journal of Environmental Studies, 29(2), 1759-1769.

[15] Sahu, A. S. (2014). Identification and mapping of the water-logged areas in Purba Medinipur part of Keleghai river basin, India: RS and GIS methods. International Journal of Advanced Geosciences, 2(2), 59-65.

[16] Sarawak Energy Berhad's Official Website. https://www.sarawakenergy.com. Last accessed 11 March 2021.

[17] Malaysia China Hydro-Joint Venture, Bakun HEP Design Report

[18] Zoungrana BJ, Conrad C, Thiel M, Amekudzi LK, and Da ED. MODIS NDVI trends and fractional land cover change for improved assessments of vegetation degradation in Burkina Faso, West Africa. Journal of Arid Environments. 2018; 153:66-75. 